\title{
Er barnebegrensning farlig?
}

\author{
Befolkningsspørsmålet var et av de store temaene i mellomkrigstiden. På den ene side var det en \\ klar befolkningstilvekst i landet som helhet, på den annen side var fruktbarheten fra begynnelsen av \\ 1900 -tallet i rask nedgang. Det var delt oppfatning om fallet i fruktbarhet. Mange syntes det var svært \\ bekymringsfullt og mente det utgjorde en trussel mot nasjonen, andre så det som en mulighet til å få \\ kontroll med den økende befolkningstilveksten. Blant de siste var blant andre professor i anatomi \\ Otto Lous Mohr (1886-1967), som mente en slik nedgang var av det gode og gjerne kunne oppmuntres \\ ytterligere. I 1926 publiserte han en artikkel i Samtiden, der han argumenterte for barnebegrensning. \\ Under bringer vi utdrag fra gynekolog Georg Benestads (1882-1957) harmdirrende respons (Tidsskr \\ Nor Lægeforen 1926; 46: 586-92). \\ I innlegget kritiserer han også en fakultetserklæring vedrørende antikonsepsjon som Mohr og hans \\ kolleger på fakultetet hadde undertegnet tre år tidligere. Blant annet het det der at «talen om de \\ befrugtningshindrende midlers skadelighet heldigvis nu er forstummet».
}

\section{Feil og begrepsforvirringer i propagandaen for en begrænsning av barnetallet.}

Av Georg Benestad, Oslo.

Ganske i motsætning til det medicinske fakultets flertal er jeg av den opfatning, at der hittil ikke er opfundet og neppe nogensinde vil bli opfundet et befrugtningshindrende middel som er saa ideelt, at et medicinsk fakultet kan gi det attest for at være absolut uten fare for sundheten, sjælelig som legemlig og likegyldig hvem der benytter det. Det middel som kan være relativt ufarlig for et egtepar, kan være meget skadelig for et andet. Man maa vel huske paa, at disse midler skal anvendes ikke av haardhudede scorta og deres venner, men av fintfølende hustruer som elsker sin mand og sine barn. Bare den ting, at der findes kvinder som er av en saa zart natur, at de ikke faar fred i sin sjæl ved tanken paa at de benytter noget saa nedværdigende, bare det er nok til at en slik attest aldrig kan gives almen gyldighet. For enkelte staar det endogsaa som en forbrydelse, som om der er kommet en mur mellem manden og hustruen, naar antikonceptionelle midler anvendes. Man skal i det hele tat være meget varsom med at utstede attester, og end mere naar det gjælder midler som griper ind i livets fineste strenger, forholdet mellem mand og hustru. Nervøsitet, psykisk depression, sjælekval er ogsaa sygdom. Og selvom det medicinske fakultet skulde ville definere sundhet saa snevert, at de kun tar hensyn til de rent legemlige forhold, saa maa man ialdfald kunne forlange, at det eller de midler som skal utstyres med denne attest maa være av den art, at man ikke faar stener for brød. Kjønsdriften lar sig likesaa litt som ernæringsdriften tilfredstille med hvadsomhelst. [...]

Et barnløst egteskap er en av de største ulykker som kan ramme et egtepar, og mange av disse ulykker maa skrives paa de befrugtningshindrende midlers konto. I det hele tat tror jeg at om publikum paa forhaand blev gjort opmerksom paa ikke alene fordelene, men ogsaa de mulige skadelige følger av fødselsreguleringen, vilde mange betakke sig for nytten av de befrugtningshindrende midler. Ihvertfald vilde deres anvendelse bli betydelig indskrænket blandt egtefolk.

Propagandaen for disse midler sker paa et falsk grundlag med falske forespeilinger og uten at der blir gjort opmerksom paa reversen. 